\title{
pH Neutralization and Zonation in Alkaline-Saline Tank Waste Plumes
}

\author{
Jiamin Wan*, Joern T. Larsen, Tetsu K. Tokunaga, and Zuoping Zheng \\ Earth Sciences Division, Lawrence Berkeley National Laboratory, Berkeley, CA 94720
}

\begin{abstract}
At the Hanford Site in Washington State, the $\mathrm{pH}$ values of contaminant plumes resulting from leaking of initially highly alkaline-saline radioactive waste solutions into the subsurface are now found to be substantially neutralized. However, the nature of plume $\mathrm{pH}$ neutralization has not previously been understood. As a master geochemical variable, $\mathrm{pH}$ needs to be understood in order to predict the fate and transport of contaminants carried by the waste plumes. Through this laboratory study, we found that the plume $\mathrm{pH}$ values spanned a broad range from 14 (within the near-source region) down to the value of 6.5 (lower than the $\mathrm{pH}$ value of the initial soil solution) while the plume was still connected to an actively leaking source. We defined 2 zones within a plume: the silicate dissolution zone (SDZ, pH 14 to 10), and the neutralized zone (NZ, pH 10 to 7). Quartz dissolution at elevated temperature and precipitation of secondary silicates (including sodium meta-silicate, cancrinite, and zeolites) are the key reactions responsible for the $\mathrm{pH}$ neutralization within the SDZ. The rapid and thorough cation exchange of $\mathrm{Na}^{+}$replacing $\mathrm{Ca}^{2+} / \mathrm{Mg}^{2+}$, combined with transport, resulted in a dynamic $\mathrm{Ca}^{2+} / \mathrm{Mg}^{2+}$ enriched plume front. Subsequent precipitation of calcite, talc, and sodium-silicate led to dramatically reduced $\mathrm{pH}$ within the plume front and the neutralized zone. During aging (after the plume source became inactive), continued quartz dissolution and the secondary-silicate precipitation drove the $\mathrm{pH}$ value lower, towards $\mathrm{pH} 11$ at equilibrium within the SDZ, whereas the $\mathrm{pH}$ values in the $\mathrm{NZ}$ remained relatively unchanged with time. A pH profile of 11 from the plume source to 7 at the plume front is expected for a historical plume. This laboratory-based study provided realistic plume $\mathrm{pH}$ profiles (consistent with that measured from borehole samples) and identified underlying mechanisms responsible for $\mathrm{pH}$ evolution.
\end{abstract}




\section{INTRODUCTION}

The Hanford Site (Washington State), operated by the U.S. Department of Energy (DOE), was a major nuclear weapons production facility from 1940 to 1989. Radioactive waste solutions were stored in underground tanks, and some of these tanks have leaked an estimated 2,300 to 3,400 $\mathrm{m}^{3}$ of waste solutions over time into the subsurface (1). Various contaminants, including radionuclides and metals, have been found at elevated concentrations in the vadose zone and groundwater underneath the Hanford tank farms (2). Besides containing high concentrations of dissolved metals and radionuclides, many of these tank waste solutions were characterized by high salinity and alkalinity, with ionic strengths in the range of 5 to $20 \mathrm{M}$ and $\mathrm{pH}$ above 10 , and some in excess of $14(3,4)$. Upon leaking, interactions between these highly reactive solutions and the underlying sediments resulted in complicated geochemical reactions, at elevated temperatures (because of radioactive decay). Over the past several years, under DOE's initiative on clean-up of the Hanford Site, studies have revealed a variety of relevant findings, including mechanisms for sorption of $\mathrm{Cs}^{+}$in sediments (5-7), formation of secondary phases through waste fluid-sediment interactions $(8,9)$, and the overall geochemical evolution of the major cations within the tank waste plumes (10).

Serne et at. (11) reported dramatically decreased (neutralized) $\mathrm{pH}$ values of tank waste plumes measured on borehole samples collected from underneath the single shell tank SX-108. The $\mathrm{pH}$ of the initial tank supernatant exceeded 14, and its ionic strength was close to $20 \mathrm{M}$ (4). However, measurements on core samples from the waste plume revealed $\mathrm{pH}$ values in the range of 10 to 7 (Figure 1). The measured major and trace element concentrations indicated that the borehole samples were certainly collected within the waste plume. What happened to all of the caustic components originally in the tank waste was an outstanding question raised by the field characterization team. The confusion surrounding this key question even left open speculation that the original waste $\mathrm{pH}$ was far less than 14 . Clear understanding is still lacking on what $\mathrm{pH}$ should be expected from the field tank waste plumes and how $\mathrm{pH}$ evolved as the plumes propagated. Since $\mathrm{pH}$ is a master geochemical variable, the behavior of waste plume contaminants, including their 
speciation, sorption, solubility, precipitation, and transport, can be reliably predicted only when the evolution of the $\mathrm{pH}$ profile is understood.

The objective of this research is to obtain this critically needed understanding on how the $\mathrm{pH}$ of initially highly alkaline and saline waste solutions evolved during plume migration through vadose zone sediments, and to identify underlying mechanisms. A plume profiling method was designed to obtain spatially and temporally direct measurements of plume geochemistry profiles. The influence of waste solution $\mathrm{pH}$, ionic strength, and sediment type were also studied. To maximize the relevance of this laboratory study for understanding real field problems, most of the

experiments involved infusion of synthetic waste solutions into sediment columns, thereby integrating the influence of reactions and transport. The advantage of transport approaches over commonly used batch methods is demonstrated through comparisons of $\mathrm{pH}$ neutralization tests.

\section{METHODS AND MATERIALS}

Sediments: The main sediment used was a Hanford Formation "coarse sand," a glaciofluvial sediment, collected from the 200 East Area of the Hanford Site. Based on our measurements, this sediment contains $93 \%$ sand, $6.0 \%$ silt, and $1.0 \%$ clay. The median grain-size is $350 \mu \mathrm{m}$, and average grain density is $2.77 \mathrm{Mg} \mathrm{m}^{-3}$. The major components are quartz, feldspar, and basaltic rock fragments, with calcium carbonate comprising $1.1 \%$ of the total mass. The $\mathrm{pH}$ of sediment water extract was 8.4 (water:soil mass ratio $=1: 1$, at $21^{\circ} \mathrm{C}$ for 24 hours). For comparisons with the Hanford sediment, two other types of porous media were also used in flow-through column experiments. The Altamont subsoil was collected at Altamont Pass (Alameda County, Califoria), at a depth of $1.0 \mathrm{~m}$. This subsoil formed from weathering of inter-bedded shale and finegrained sandstone, and contains high calcite (10\%) and clay concentrations (28\%, primarily smectite). High-purity quartz sand (Accusand, Unimin Company, Ottawa, Minnesota) with grainsize ranging from 225 to $425 \mu \mathrm{m}$, was used as the final sediment. 
Synthetic Tank Waste Solution: The chemical composition of the synthetic tank waste solution (TWS) used in most experiments was based on historical and direct measurements from the single shell tank SX-111 (3), and was a good representative of its waste type. It contained 4.72 $\mathrm{M} \mathrm{NO}_{3}^{-}, 1.47 \mathrm{M} \mathrm{OH}^{-}, 0.84 \mathrm{M} \mathrm{NO}_{2}^{-}, 0.17 \mathrm{M} \mathrm{CO}_{3}{ }^{2-}, 0.06 \mathrm{M} \mathrm{SO}_{4}{ }^{2-}, 0.81 \mathrm{M} \mathrm{Al}^{3+}$, and $8.32 \mathrm{M} \mathrm{Na}^{+}$. No other metals or radionuclides were included in the TWS, because this study is aimed at identifying major interactions between waste solutions and sediments. The solution density was 1.37 $\mathrm{Mg} \mathrm{m}^{-3}$, and all added salts were completely dissolved within hours of stirring at room temperature. The solution was filtered $(0.45 \mu \mathrm{m})$ before use. In the flow-through column experiments, two sets of simpler solutions were used for comparisons with the TWS. In testing ionic strength effects, four solutions of different ionic strength $(1,3,5$, and $8 \mathrm{M}$, with a common concentration of $1.0 \mathrm{M}_{\left.\left[\mathrm{OH}^{-}\right]\right)}$) were used. These solutions contained only $\mathrm{NaNO}_{3}$ and $\mathrm{NaOH}$. In testing $\mathrm{pH}$ effects, four solutions of different $\left[\mathrm{OH}^{-}\right]$contents $(1.0,0.1,0.01$, and $0.001 \mathrm{M} \mathrm{NaOH}$ with a common ionic strength of $8 \mathrm{M}$ ) were used. These solutions also contained only $\mathrm{NaNO}_{3}$ and $\mathrm{NaOH}$.

Laboratory Plume Profiling Method: The general approach taken in this study was to simulate the tank waste leakage event by infiltrating synthetic tank waste solutions into Hanford sediment columns at elevated temperature. By doing so, the geochemical reactions and transport processes are studied in an integrated manner and are directly relevant to field conditions. The experimental conditions were chosen as close as possible to that of the Hanford vadose zone, but at the same time designed simple enough so that causes and effects could be clearly identified. We developed the plume profiling method to obtain direct measurements of plume $\mathrm{pH}$ and chemical profiles (Figure 2), i.e., spatially resolved information on the solution and solid phases at any desired time.

Three columns $(0.2,0.5$, and $2.0 \mathrm{~m}$ long) were used to obtain chemical profiles in plumes of different lengths. The Hanford sediment prepared with $6 \%$ mass initial moisture (mixing the dry sediment with deionized water) was homogeneously packed into each column to an equivalent dry bulk density of $1.65 \mathrm{Mg} \mathrm{m}^{-3}$. The sediment column was inserted into an outer column that provided 
temperature control through connection with a recirculating temperature-regulating water bath. All the experiments were conducted with the column temperature maintained at $70 \pm 1.0^{\circ} \mathrm{C}$. The TWS was injected into the sediment column with syringe pump, at a pore-water velocity of $100 \mathrm{~mm} \mathrm{~d}^{-1}$. To avoid gravity-induced flow fingering, the fluid was injected from the bottom of the vertically oriented columns. Therefore, each column was nearly saturated at the time outflow occurred. In order to facilitate comparisons with the field plume geometry, our data are graphed with the plume source at the top. When effluent (displaced initial soil water) was detected to just emerge at the outlet, injection was terminated and the column was immediately sectioned at 20, 25, and $50 \mathrm{~mm}$ intervals for the $0.2,0.5$, and $2.0 \mathrm{~m}$ columns, respectively. Pore solution samples were immediately vacuum-extracted from each column segment. These solutions extracted from individual segments were then analyzed for their $\mathrm{pH}$ and electrical conductivity (EC). The resulting spatially resolved analyses permitted reconstruction of waste-plume $\mathrm{pH}$ profiles.

Plume Aging: The aforementioned procedure was used to study plume chemical composition at the time of leakage, while the plume was still connected with an active source. However, after the plume source became inactive, reactions would continue and the plume $\mathrm{pH}$ profile would continue to evolve toward equilibrium. Aging experiments were conducted with a 0.5 m tall column, under the same conditions as that described in the previous paragraph, up to the step of column sectioning. For studying the plume aging process, we sectioned the plume (column) at the onset of outflow, to prevent diffusive smearing of chemical profiles during longer-term storage. The column was sectioned into $25 \mathrm{~mm}$ long segments, and each segment was homogenized and then divided to four subsamples. Pore liquid was immediately removed from one of the four subsamples by centrifugation extraction, and its $\mathrm{pH}$ and $\mathrm{EC}$ were measured. The remaining three subsamples from each segment were packed into individual plastic vials and aged at $70^{\circ} \mathrm{C}$ for different lengths of time: 4, 22, and 44 days. Each subsample was analyzed for its pore liquid $\mathrm{pH}$ and EC at the time of sampling. The resulting spatially and temporally resolved analyses permitted reconstruction of plume $\mathrm{pH}$ changes over time. 
Batch tests: For comparisons with the flow systems, batch tests were conducted to study pH changes with time under hydrostatic conditions. To keep all other conditions as similar as possible to the plume-profiling columns, samples of the Hanford sediment (with 6\% mass initial moisture) were packed into individual $40 \mathrm{~mL}$ vials, each to the bulk density of $1.65 \mathrm{Mg} \mathrm{m}^{-3}$. The TWS was added to the packed sediment vials to $95 \%$ of saturation. A total of 15 batch samples were prepared in the same manner. The vials were immersed in a water bath controlled at $70 \pm 1^{\circ} \mathrm{C}$ and then periodically opened to the atmosphere to match the plume-profiling column condition. At selected elapsed times, one of the vials was removed from the water bath, its pore solution was extracted, and the $\mathrm{pH}$ value was measured.

Flow-through Column Tests: Studies on the effect of salinity and initial waste solution $\mathrm{pH}$, as well as sediment type, on plume $\mathrm{pH}$ evolution were conducted using a conventional flow-through column method. This set of experiments was conducted at room temperature (instead of the $70^{\circ} \mathrm{C}$ used in plume profiling experiments) for the sake of simplicity. The flow-through columns were $250 \mathrm{~mm}$ long, had an inner diameter of $38 \mathrm{~mm}$, and were oriented vertically, with flow directed upward. The same packing density $\left(1.65 \mathrm{Mg} \mathrm{m}^{-3}\right)$ and flow velocity $\left(100 \mathrm{~mm} \mathrm{~d}^{-1}\right)$ as that used in the plume profiling experiments were used in the flow-through experiments. Tests of salinity effects were motivated by field (11) and laboratory (10) results that showed the importance of $\mathrm{Na}^{+}$in the waste solution displacing $\mathrm{Ca}^{2+}$ from cation exchange sites in sediment. In testing the effects of salinity (specifically $\mathrm{Na}^{+}$concentrations), we used four solutions of different ionic strength. All of these solutions contained $1.0 \mathrm{M} \mathrm{NaOH}$ and varying amounts of $\mathrm{NaNO}_{3}$ to provide ionic strengths of $1,3,5$, and $8 \mathrm{M}$.

In testing the effect of the initial waste solution $\mathrm{pH}$ on plume $\mathrm{pH}$ changes, four solutions containing different amounts of $\mathrm{NaOH}, 0.001,0.01,0.1$, and $1.0 \mathrm{M}$, were injected through Hanford sediment columns. The common ionic strength of all four solutions was $8.0 \mathrm{M}$, obtained by adding appropriate amounts of $\mathrm{NaNO}_{3}$. To test the influence of sediment type on $\mathrm{pH}$ evolution, Altamont soil and quartz sand were permeated with the TWS for comparison with Hanford sediments. In all these aforementioned flow-through column tests, a fluid volume equivalent to two pore volumes was 
injected using syringe pumps, and effluent samples were collected using fraction collectors.

pH and EC Measurements: pH measurements were obtained with a Corning Semi-Micro combination glass $\mathrm{pH}$ electrode. This electrode was connected to a Denver Instrument Model 225 pH/ISE meter. Calibrations were done with $\mathrm{pH} 4,7,10$ standards (JT Baker), and a $0.10 \mathrm{M} \mathrm{NaOH}$ solution as a pH 13 standard. Recall that many of the experiments were conducted at high ionic strengths and elevated temperatures, whereas $\mathrm{pH}$ measurements were conducted at room temperature. Therefore, the reported $\mathrm{pH}$ values are intended for comparisons among the different systems rather than for inferring actual proton or hydroxyl activities under these extreme experimental conditions. EC measurements were conducted on solutions that were diluted 100-fold. This level of dilution provided EC values that were linearly correlated with ionic strength.

Modeling: The plume aging and batch laboratory results were compared with geochemical modeling predictions. As described earlier, the laboratory aging tests were conducted in a batch manner, without flow. (The chemical reactions considered in the model calculations are based on our conceptual model, described later). The Bio-Core ${ }^{2 \mathrm{D} \odot}$ code (12) was used. This code couples geochemical and transport processes, and was recently augmented with Pitzer's ion interaction model (13) for handling reactive transport of high ionic strength solutions. Mineral precipitation and dissolution reactions were kinetically formulated by using rate laws following Lasaga et al. (14).

\section{RESULTS AND DISCUSSION}

\section{Measured pH Profiles from Plume-Profile Columns}

The $\mathrm{pH}$ and EC profiles measured along the three laboratory-simulated waste plumes $(0.2,0.5$, and $2.0 \mathrm{~m}$ long) are presented in Figure 3, with positions plotted in terms of normalized distance relative to the plume length. Plotting with respect to normalized distance facilitates evaluating whether these basic characteristics of the plume scale linearly with respect to the permeated solution

volume. This normalized distance axis in this figure is oriented to reflect the field geometry with 
downward migration of the waste solution. The normalized distance was obtained by dividing sample distances (away from the top of the column) by the plume length. The plume front was determined using the inflection point of the normalized EC profile (Figure 3B), which indicates mixing of high-saline TWS with the displaced native soil water, which has the value of normalized EC close to zero. Normalized EC refers to the electrical conductivity of 100 -fold diluted pore waters, relative to that of the initial TWS at the same dilution.

Moving away from the TWS source within the plume, $\mathrm{pH}$ and salinity (normalized EC) decline as the plume front is approached. The normalized distance of 1 denotes the predicted plume front, and the salinity data show that this position is in fact at the inflection point of the normalized EC profiles. The plume front marks the boundary between the displaced native soil water zone and the waste plume. This displaced soil-water zone contains primarily displaced native soil-water, and is characterized by its normalized EC being closed to zero and its $\mathrm{pH}$ being close to 8 . The displaced soil water zone exhibits increased mixing with neutralized TWS as the plume front is approached.

Dramatic $\mathrm{pH}$ reduction of the waste plumes was recorded, from 14 at the plume source to as low as 6.5 near the plume front. (Reactions responsible for $\mathrm{pH}$ reduction are discussed in the next section.) Because of the large range of plume $\mathrm{pH}$ values and resulting wide range of geochemical properties of the plume, we define the plume as two broad zones: the silicate dissolution zone (SDZ) and neutralized zone (NZ). A pH value of 10 was assigned as the boundary, simply because silicate dissolution becomes relatively insignificant at $\mathrm{pH}$ below 10 . The results indicate that within the tested range, plumes of different depths showed the same values and distributions of $\mathrm{pH}$ when examined in terms of normalized distance. These results led to the conclusion that the extent and zoning of $\mathrm{pH}$ neutralization recorded in our laboratory-simulated plumes are expected to have occurred in the field during the period of active leakage.

\section{Conceptual Model for pH Neutralization}

The evolution of plume $\mathrm{pH}$ of the highly alkaline-saline waste plumes is complex, involving a large number of chemical reactions, transport processes, and elevated temperatures. In this section, 
we provide a conceptual model for plume $\mathrm{pH}$ evolution. This model is based on our laboratory column results presented in this paper, plume solute and solid phase geochemistry presented in Wan et al. (10), and some of our unpublished results including XRD, EDX, and SEM data on secondary precipitates collected during these column experiments.

Recall that the TWS is characterized by a very high $\mathrm{Na}^{+}$concentration, with a $\mathrm{pH}$ of 14 . Leakage of this solution into the calcareous sediments led to displacement of $\mathrm{Ca}^{2+}$ (as well as $\mathrm{Mg}^{2+}$, which together comprise at least $92 \%$ of the initial exchangeable cations (15) from cation exchange sites of the sediment by $\mathrm{Na}^{+}$:

$$
2 \mathrm{Na}^{+}+\mathrm{Ca}-\mathrm{X} \square \quad \mathrm{Na}_{2}-\mathrm{X}+\mathrm{Ca}^{2+}
$$

Being a cation exchange reaction, the release of $\mathrm{Ca}^{2+} / \mathrm{Mg}^{2+}$ upon exposure to the waste solution is rapid. The extremely high $\mathrm{Na}^{+}$concentration in the waste solution drove this cation-exchange reaction to completion. At the same time, transport kept the zone of exchanged divalent cations at the moving front of the waste plume, where $\mathrm{Ca}^{2+} / \mathrm{Mg}^{2+}$ accumulated to elevated levels. The measured $\mathrm{Ca}^{2+} / \mathrm{Mg}^{2+}$ concentrations were as high as $1.2 \mathrm{M} / 0.4 \mathrm{M}$ within the plume front of the $2.0 \mathrm{~m}$ column, and $0.5 \mathrm{M} / 0.2 \mathrm{M}$ in the $0.5 \mathrm{~m}$ column (10). These concentrations are consistent with calculated concentrations resulting from cation exchange, based on cation exchange capacity data of the Hanford sediment (values from 17 to $180 \mathrm{mmol}_{\mathrm{c}} \mathrm{kg}^{-1}$ reported by Serne et al. (15) and discussed by Wan et al. (10).

Simultaneously, dissolution of silicate minerals is significant under the highly alkaline and elevated temperature conditions, as evidenced by elevated Si concentrations in the extracted pore fluids and depleted Si concentrations in the reacted sediments (10) within the silicate dissolution zone $(\mathrm{pH} \geq 10)$. Quartz dissolution is one of the most important reactions responsible for $\mathrm{pH}$ reduction in the SDZ (eq 2).

$$
\mathrm{SiO}_{2}(\mathrm{~s})+2 \mathrm{H}_{2} \mathrm{O}=\mathrm{H}_{2} \mathrm{SiO}_{4}{ }^{2-}+2 \mathrm{H}^{+}
$$


Quartz dissolution was enhanced by the subsequent silica precipitation. Because of the extremely high concentration of $\mathrm{Na}^{+}$in the solution, precipitation of sodium meta-silicate is favored (eq 3). However, we only identified $\mathrm{Na}_{2} \mathrm{SiO}_{3}$ (SEM and EDX) within and just behind the plume front. Thus, sodium meta-silicate may be a transient phase in the region near the plume source. Cancrinite, zeolites (including $\mathrm{Na}_{2} \mathrm{Al}_{2} \mathrm{Si}_{1.85} \mathrm{O}_{7.7} \cdot 5.1 \mathrm{H}_{2} \mathrm{O}, \mathrm{Na}_{14} \mathrm{Al}_{12} \mathrm{Si}_{13} \mathrm{O}_{51} \cdot 6 \mathrm{H}_{2} \mathrm{O}$, and $3 \mathrm{NaAlSiO}_{4} \mathrm{Na}_{2} \mathrm{CO}_{3}$ ), and zeolite-like crystalline and amorphous phases were identified (XRD and SEM) as the dominant secondary phases formed within the silicate dissolution zone (9). Cancrinite was found to be the most abundant secondary phase, and eq 4 represents formation of this group of precipitates, which play an important role in enhancing quartz dissolution:

$$
\begin{gathered}
\mathrm{H}_{4} \mathrm{SiO}_{4}+2 \mathrm{Na}^{+}=\mathrm{Na}_{2} \mathrm{SiO}_{3}+\mathrm{H}_{2} \mathrm{O}+2 \mathrm{H}^{+} \\
6 \mathrm{H}_{2} \mathrm{SiO}_{4}{ }^{2-}+6 \mathrm{Al}(\mathrm{OH})_{4}{ }^{-}+8 \mathrm{Na}^{+}+2 \mathrm{NO}_{3}{ }^{-}=\mathrm{Na}_{8}\left(\mathrm{AlSiO}_{4}\right)_{6}\left(\mathrm{NO}_{3}\right)_{2} \cdot 4 \mathrm{H}_{2} \mathrm{O}+8 \mathrm{H}_{2} \mathrm{O}+12 \mathrm{OH}^{-}
\end{gathered}
$$

Besides sodium, the TWS also contained a high concentration of dissolved aluminum (0.8 M). In addition to precipitating with $\mathrm{Na}$ and $\mathrm{Si}$ (eq 4), $\mathrm{Al}$ also precipitated with $\mathrm{Ca}^{2+} / \mathrm{Mg}^{2+}$ (from eq 1) as described in eqs 5 and 6 . These two reactions were identified in our experiments on the effect of temperature (data are not shown). Ettringite and $(\mathrm{CaO})_{3} \cdot \mathrm{Al}_{2} \mathrm{O}_{3} \cdot \mathrm{CaCO}_{3} \cdot 11 \cdot \mathrm{H}_{2} \mathrm{O}$ were identified in those room temperature experiments as the major secondary phases. Although the focus of this paper is on $\mathrm{pH}$ neutralization mechanisms under elevated temperature, these reactions important at lower temperature are also worth reporting since the subsurface temperature is variable. Formation of these phases significantly contributed to $\mathrm{pH}$ reduction of plume front under ambient temperature condition.

$$
4(\mathrm{Ca}, \mathrm{Mg})^{2+}+2 \mathrm{Al}(\mathrm{OH})_{4}{ }^{-}+\mathrm{CO}_{3}{ }^{2-}+9 \mathrm{H}_{2} \mathrm{O}=[(\mathrm{Ca}, \mathrm{Mg}) \mathrm{O}]_{3} \cdot \mathrm{Al}_{2} \mathrm{O}_{3} \cdot \mathrm{CaCO}_{3} \cdot 11 \cdot \mathrm{H}_{2} \mathrm{O}+4 \mathrm{H}^{+}
$$




$$
6(\mathrm{Ca}, \mathrm{Mg})^{2+}+2 \mathrm{Al}(\mathrm{OH})_{4}^{-}+3 \mathrm{SO}_{4}{ }^{2-}+30 \mathrm{H}_{2} \mathrm{O}=\left(\mathrm{Ca}, \mathrm{Mg}_{6} \mathrm{Al}_{2}\left(\mathrm{SO}_{4}\right)_{3}(\mathrm{OH})_{12} \cdot 26 \mathrm{H}_{2} \mathrm{O}+4 \mathrm{H}^{+}\right.
$$

As previously mentioned, the plume front liquid contained high concentrations of $\mathrm{Ca}^{2+}, \mathrm{Mg}^{2+}$, and $\mathrm{Na}^{+}$, leading to precipitation of calcite, talc, and amorphous (or poorly crystalline) sodiumsilicate. Formations of these phases (eqs 3, 7, and 8) were responsible for the dramatic pH reduction to $\leq 7.0$ within the plume front.

$$
\begin{gathered}
\mathrm{Ca}^{2+}+\mathrm{CO}_{2}+\mathrm{H}_{2} \mathrm{O}=\mathrm{CaCO}_{3}+2 \mathrm{H}^{+} \\
4 \mathrm{H}_{4} \mathrm{SiO}_{4}+3 \mathrm{Mg}^{2+}=\mathrm{Mg}_{3} \mathrm{Si}_{4} \mathrm{O}_{10}(\mathrm{OH})_{2}+4 \mathrm{H}_{2} \mathrm{O}+6 \mathrm{H}^{+}
\end{gathered}
$$

However, under the lower temperature condition, in addition to calcite formation, the precipitates resulting from the eqs 5-6 reactions also contributed to the large $\mathrm{pH}$ reduction at and near the plume front. The reactions (eqs 1-8) are all supported by measurements and are believed to be the major processes controlling plume $\mathrm{pH}$ neutralization and zonation. Given the complexity of the system, it is likely that other reactions also influenced the plume $\mathrm{pH}$ evolution.

\section{Results from Flow-through Column Experiments}

The following experiments provided further testing of the conceptual model presented in the previous section. The all three sets of experiments were conducted in $250 \mathrm{~mm}$ Hanford sediment columns, at $21^{\circ} \mathrm{C}$ and with a pore-water velocity of $100 \mathrm{~mm} \mathrm{~d}^{-1}$. The effluent fluids were collected and analyzed for their $\mathrm{pH}$ and $\mathrm{EC}$.

Effect of Ionic Strength: Figure 4 shows breakthrough curves obtained with inflow solutions of different ionic strength (specifically, different $\mathrm{Na}^{+}$concentrations): 8.0, 5.0, 3.0, and $1.0 \mathrm{M}$, with a common $\mathrm{OH}^{-}$concentration of $1.0 \mathrm{M}$. Duplicate runs were conducted with the $1.0 \mathrm{M}$ ionic strength solution. The plume front was determined by the inflection point of the measured normalized EC breakthrough curve (not shown) and is indicated on the pore volume axis by the 
arrow. The results show that the curves from solutions of ionic strength $8.0,5.0$, and $3.0 \mathrm{M}$ exhibited the same $\mathrm{pH}$ minima at the plume front, with values lower than that of the displaced native soil water. However, the $1.0 \mathrm{M}$ solution did not depress $\mathrm{pH}$ at the plume front as much as the solutions with higher ionic strength.

The major reactions responsible for the plume front $\mathrm{pH}$ neutralization in this study are those described in eqs 7 and 8 . Since the experiments were conducted at room temperature, where quartz solubility is much lower than at $70^{\circ} \mathrm{C}$, the reactions described by eqs 2,3 , and 4 are not as significant as they would be at elevated temperature. The influent solution did not contain Al, so that the reactions described by eqs 5 and 6 are not important. These results give further support to cation exchange of $\mathrm{Na}^{+}$replacing $\mathrm{Ca}^{2+}$ and $\mathrm{Mg}^{2+}$, and subsequent precipitation (eqs 7-8) as the mechanisms controlling the dramatic $\mathrm{pH}$ reduction at the plume front and the neutralized zone. Higher $\mathrm{Na}^{+}$concentrations provided more effective $\mathrm{Na}^{+}$displacement of $\mathrm{Ca}^{2+} / \mathrm{Mg}^{2+}$ on cation exchange sites of the sediment. The condition of $\mathrm{Na}^{+}$being higher than $1.0 \mathrm{M}$, and perhaps as high as about $3.0 \mathrm{M}$, is required to thoroughly replace all the $\mathrm{Ca}^{2+} / \mathrm{Mg}^{2+}$ sites in the sediment and to reduce the $\mathrm{pH}$ at the plume front to its minima.

Effect of Initial pH: The breakthrough curves of solutions with different influent pH (13.8, $12.9,10.8$, and 9.3), with a common ionic strength of $8.0 \mathrm{M}$ (containing only $\mathrm{NaNO}_{3}$ and $\mathrm{NaOH}$ ) are presented in Figure 5. Again, the plume front was determined using the inflection points of the measure normalized EC curve. The same minima of $\mathrm{pH} 6.7$ at the plume front was obtained for all the influent solutions of different $\mathrm{pH}$. This result indicates that the initial $\mathrm{pH}$ of the tank waste solution did not control $\mathrm{pH}$ neutralization at the plume front and the neutralized zone. Cation exchange of $\mathrm{Na}^{+}$for $\mathrm{Ca}^{2+}$ and $\mathrm{Mg}^{2+}$ (eq 1), and their subsequent precipitation (eqs 7 and 8 ) were responsible for $\mathrm{pH}$ neutralization observed in this study. The data also show that the curve from the $\mathrm{pH} 13.8$ solution reached its influent $\mathrm{pH}$ value after one pore volume of injection, whereas the $\mathrm{pH}$ values of the other three curves remained low, apparently because the $\mathrm{OH}^{-}$content in the three lower $\mathrm{pH}$ solutions was largely consumed. 
Effect of Sediment Type: In addition to the Hanford sediment, a clay-rich Altamont soil and quartz sand were tested to examine $\mathrm{pH}$ neutralization in different types of sediments. The waste solution used in this study was the simulated TWS $(\mathrm{pH}=14, I=8 \mathrm{M}$, composition presented in the method section). Duplicate runs were conducted for quartz sand. The location of the plume front was determined by using the inflection point of the normalized EC curve presented in Figure 6B. We found that $\mathrm{pH}$ values at the plume front are 6.7 for the Hanford and Altamont soils and 13.5 for the quartz sand (Figure 6A). The absence of a pH minimum in the quartz sand reflects its negligible cation exchange capacity, and the later slight $\mathrm{pH}$ reduction reflects quartz dissolution $\left(21^{\circ} \mathrm{C}\right)$. Note that the displaced initial pore waters in the quartz sand did become significantly more acidic $(\mathrm{pH}$ as low as 4.0) than its water extract $(\mathrm{pH} \approx 7)$. An explanation for the acidification of the displaced initial pore waters was not found. The Altamont soil exhibited a similar but larger $\mathrm{pH}$-neutralized zone than the Hanford sediment, suggesting that the same plume $\mathrm{pH}$-neutralization phenomena can occur within any host sediments/soils that have enough exchangeable divalent cations. The broader $\mathrm{pH}$-neutralization zone for the Altamont soil reflects a greater cation exchange capacity (about 250 $\mathrm{mmol}_{\mathrm{c}} \mathrm{kg}^{-1}$ ) than the Hanford sand. These results further support the conceptual model of plume $\mathrm{pH}$ evolution presented in the previous section. Cation exchange of $\mathrm{Na}^{+}$for $\mathrm{Ca}^{2+} / \mathrm{Mg}^{2+}$ is the key factor for the large $\mathrm{pH}$ reduction at the plume front and within the $\mathrm{pH}$ neutralized zone.

\section{Plume pH Profiles upon Aging}

At contaminated sites, a waste plume from a finite tank source would eventually become inactive, while waste-sediment interactions continue. Thus, it is important to know how the plume $\mathrm{pH}$ evolved and what $\mathrm{pH}$ values should be expected for an aged plume. Four $\mathrm{pH}$ profiles measured from aging experiments at different times are presented in Figure 7 (data points). The time zero $\mathrm{pH}$ profile, representing the plume $\mathrm{pH}$ with an active source, was measured immediately after the TWS source was disconnected from the column. The data showed that the initial plume profile spanned the $\mathrm{pH}$ range from about 14 (within the near-source region) down to 6.7 (at the plume front). Within the SDZ, after the plume had been disconnected from its source for 4, 22, and 44 days, $\mathrm{pH}$ 
values decreased with a rapidly reduced rate (the rate became significantly lower after 22 days). The $\mathrm{pH}$-controlling reactions during aging are believed to be quartz dissolution and sodium-metasilicate and cancrinite precipitation (eqs 2,3, and 4). No significant $\mathrm{pH}$ changes were observed within the $\mathrm{NZ}$, apparently because reactions in the NZ had reached equilibrium, and there were no additional inputs of $\mathrm{Al}, \mathrm{Ca}$, and $\mathrm{Mg}$. The $\mathrm{pH}$ values of displaced soil water experienced changes in both directions and eventually reached equilibrium with the atmosphere $\mathrm{CO}_{2}$ and sediment carbonate at $\mathrm{pH}$ values around 8 (the $\mathrm{pH}$ of the initial sediment pore water).

Model calculations of $\mathrm{pH}$ values during the aging process in the SDZ are shown in Figure 7 as lines. In these model calculations, the measured $\mathrm{pH}$ values at day 0 were used as the initial $\mathrm{pH}$ of each local calculation. Quartz dissolution and sodium-metasilicate and cancrinite precipitation (eqs 2, 3, and 4) were considered the dominant reactions. Quartz dissolution is often described as a kinetic process in numerous experimental and modeling studies (e.g., 16-20). Although a wide range of rates has been reported for this key reaction (21), we assumed quartz dissolution under alkaline conditions depends on $\left[\mathrm{OH}^{-}\right]^{0.3}$ based on several studies (22-24). The empirical rate expression $\left(\mathrm{mol} \mathrm{Si} \mathrm{s}{ }^{-1}\right)=\left(\mathrm{a}_{\mathrm{q}} \mathrm{k}_{\mathrm{q}}\right)\left[\mathrm{OH}^{-}\right]^{0.3}$ was optimized by varying the lumped parameter $\mathrm{a}_{\mathrm{q}} \mathrm{k}_{\mathrm{q}}$, which combines the reactive quartz surface area $\left(\mathrm{a}_{\mathrm{q}}\right)$ with the rate constant $\left(\mathrm{k}_{\mathrm{q}}\right)$. The best fit, obtained with $\left.\mathrm{a}_{\mathrm{q}} \mathrm{k}_{\mathrm{q}}=5 \times 10^{-3}(\mathrm{~mol} \mathrm{~m})^{-3}\right)^{0.7} \mathrm{~s}^{-1}$ is shown as the curve in Figure 7. As quartz dissolution took place, precipitation of amorphous sodium silicate (silica gel) was expected (eq 3) because of the coexisting high $\mathrm{H}_{2} \mathrm{SiO}_{4}{ }^{2-}, \mathrm{H}_{3} \mathrm{SiO}_{4}^{-}$, and $\mathrm{Na}^{+}$concentrations. This process can be approximately described by linear kinetics, depending on $\mathrm{Na}^{+}$and $\mathrm{H}_{2} \mathrm{SiO}_{2}{ }^{2-}$ concentrations (25). The rate constant was used is a fitting parameter, leading to $\left(\mathrm{mol} \mathrm{Na} \mathrm{SiO}_{3} \mathrm{~s}^{-1}\right)=1.10 \times 10^{-5}\left[\mathrm{Na}^{+}\right]\left[\mathrm{H}_{2} \mathrm{SiO}_{4}{ }^{2-}\right]$. The mineral cancrinite is a feldspathoid, and similar to zeolite in that it too has a porous aluminosilicate framework structure $(26,27)$. In the literature, the formation of cancrinite and zeolite is regarded as the kinetically controlled processes $(8,28-31)$. The formation of cancrinite increases approximately linearly with respect to concentrations of Si and $\mathrm{Al}(28)$. The approaches by Mostafa et al. (32, 33) were used to estimate thermodynamic data for eq 4 . Modeled $\mathrm{pH}$ results show fair agreement with the measurements. When all considered mineral phases come to equilibrium with the highly saline- 
alkaline solution, a $\mathrm{pH}$ of 10.8 was obtained (shown as the heavy dished line in figure 7 ). Note that the model calculations were for conditions of a closed system at $70^{\circ} \mathrm{C}$. Despite more variable conditions in the field (more open to atmosphere and with temperature decreasing over time), these results provide a reasonable prediction for the effect of aging on plume $\mathrm{pH}$ evolution. An aged tank waste plume has a $\mathrm{pH}$ profile from about 11 near source region to 7 at the plume front.

\section{Comparison with Batch Equilibrium Tests}

To evaluate the importance of flow and transport on plume $\mathrm{pH}$ neutralization, batch tests were conducted under conditions that are similar to that of the column-profiling experiments. Figure 8 (data points) shows measured $\mathrm{pH}$ changes with time. The data show that $\mathrm{pH}$ decreased with time at progressively reduced rates. By Day 40, the $\mathrm{pH}$ was reduced to around 11.6. Geochemical modeling of the batch tests was conducted considering the reactions described in eqs 1-6. The reactions in eqs 2-4 were treated as rate limited reactions in the same manner as described in the plume aging modeling. The reactions in eqs 1, 5, and 6 were treated as equilibrium processes. The model prediction (Figure 5 curve) shows good agreement with the measurements. Based on the model calculations, the system will eventually reach equilibrium at $\mathrm{pH}$ value 10.8 .

The conventional batch approach can only provide an equilibrium $\mathrm{pH}$ value for a static tank waste plume (Figure 8), whereas the plume-profiling method permitted measurements of the full range of spatially ordered $\mathrm{pH}$ values and enabled us to identify the $\mathrm{pH}$ neutralization zone (Figure 3 and 7). Thus, without the use of this plume profiling method, mechanisms involved in plume $\mathrm{pH}$ neutralization and zonation would not have been found.

In summary, we have revealed how the $\mathrm{pH}$ of initially highly alkaline-saline waste plumes evolved upon leakage at the elevated temperature. During active leakage, the plume $\mathrm{pH}$ values vary from the $\mathrm{pH}$ of the initial waste solution within the near-source region down to a $\mathrm{pH} \approx 6.5$ at the plume front. Dissolution of primary minerals and precipitation of secondary silicates drove the $\mathrm{pH}$ down significantly within the SDZ. Rapid and thorough cation exchange of $\mathrm{Na}^{+}$for $\mathrm{Ca}^{2+} / \mathrm{Mg}^{2+}$, combined with transport, caused a dynamic $\mathrm{Ca}^{2+} / \mathrm{Mg}^{2+}$ enriched plume front. The subsequent 
precipitation of calcite, talc, and sodium-silicate reduced the $\mathrm{pH}$ of the plume front to values lower than that of the initial pore waters. After the plume source became inactive and the plume aged, continued silicate dissolution and sodium meta-silicate and cancrinite/zeolite precipitation drove the $\mathrm{pH}$ lower, towards $\mathrm{pH} 11$ within the silicate dissolution zone, while the $\mathrm{pH}$ values in the neutralized zone remained relatively unchanged. A pH profile of 11.0 from the plume source to 7.0 at the plume front is expected for an aged plume. These results are consistent with the measured plume $\mathrm{pH}$ profile from field borehole samples. This laboratory study of $\mathrm{pH}$ evolution will help improve understanding and predictions of contaminant behavior in alkaline-saline waste plumes.

\section{Acknowledgments}

This work was carried out under U.S. Department of Energy Contract No. DE-AC03-76SF-00098. This research was supported by the Environmental Management Science Program of the Office of Science, U.S. Department of Energy. The authors thank Patrick Dobson (LBNL) for the helpful internal review and Daniel Hawkes (LBNL) for internal editing of this manuscript.

\section{References}

(1) DOE, Vadose zone characterization project at the Hanford Tank Farms-SX Tank Farm. DOE/ID/12584-268, 1996, U. S. Department of Energy, Grand Junction, Colorado.

(2) Ward, A. L.; Gee, G. W.; White, M. D. A comprehensive analysis of contaminant transport in the vadose zone beneath tank SX-109, PNNL-11463, 1997, Pacific Northwest National Laboratory, Richland, Washington.

(3) Agnew, S. F.; Boyer, J.; Corbin, R. A.; Duran, T. B.; Fitzpatrick, J. R.; Jurgensen, K. A.; Ortiz, T. P.; Young, B. L. Hanford tank chemical and radionuclide inventories: HDW Model Rev. 3. LA-UR-96-858, 1996, Los Alamos National Laboratory, Los Alamos, NM.

(4) Jones, T. E.; Maclean, G. T. Inventory estimates for single-shell tank leaks in S and SX tank farms, RPP-6285, 2000, CH2MHILL Hanford Group, Inc., Richland, Washington. 
(5) Serne, R. J.; Zachara, J. M.; Burke, D. S. Chemical information on tank supernatants, Cs adsorption from tank liquids onto Hanford sediments, and field observations of Cs migration from past tank leaks, PNNL-11495, 1998, Pacific Northwest National Laboratory, Richland, Washington.

(6) Zachara, J. M.; Smith, S. C.; Liu, C.; McKinley, J. P.; Serne, R. J.; Gassman, P. L. Geochim. Cosmochim. Acta. 2002, 66, 193-211.

(7) McKinley, J. P.; Zeissler, C. J.; Zachara, J. M.; Serne, R. J.; Lindstrom, R. M.; Schaef, R.T.; Orr. R.D. Environ. Sci. Technol. 2001, 35, 3433-3441.

(8) Bickmore, B. R.; Nagy, K. L.; Young, J. S.; Drexler, J. W. Environ. Sci. Technol. 2001, 35, 4481-4486.

(9) Wan, J.; Tokunaga, T. K.; Saiz, E;; Couture, R. A.; Olson, K. R.; Larsen, J. T. Colloid formation resulting from highly alkaline and saline waste tank solution leaking into sediments at the Hanford site. LBID-2446, 2003, Lawrence Berkeley National Laboratory, Berkeley, California.

(10) Wan, J.; Tokunaga, T. K.; Larsen, J. T.; Serne, R. J., Geochemical Evolution of Highly Alkaline and Saline Tank Waste Plumes During Seepage through Vadose Zone Sediments Geochim. Cosmochim. Acta, 2003, accepted.

(11) Serne, R. J.; Clayton, R. E.; Kutnyakov, I. V.; Last, G. V.; LeGore, V. L.; Wilson, T. C.; Schaef, H. T.; O’Hara, J.; Wagnon, K. B.; Lanigan, D. C.; Brown; C. F.; Williams, B. A.; Lindenmeier, C. W.; Orr, R. D. Geologic and Geochemical Data Collected from Vadose Zone Sediments from the Slant Borehole SX -108 in the S/SX Waste Management Area and Preliminary Interpretations, PNNL-99352, 2001a, Pacific Northwest National Laboratory, Richland, Washington.

(12) Zhang, G. Nonisothermal Hydrobiogeochemical Models in Porous Media, Ph.D. dissertation, 2001, University of La Coruña, Spain.

(13) Pitzer, K. S. In Activity Coefficients in Electrolytes Solutions, edited by Pitzer, K. S. 2nd, 1991, CRC Press, 75-155. 
(14) Lasaga, A.C.; Soler, J.M.; Ganor, J.; Burch, T.E.; Nagy, K.L. Geochim. Cosmochim. Acta, 1994, 58, 2361-2386.

(15) Serne, R. J.; LeGore, V. L.; Last, G. V.; Schaef, H. T.; O’Hara, M. J.; Smith, S. C.; Bjornstad, B. N.; Brown, C. F.; Lindenmeier, C. W.; Williams, B. A.; Parker, K. E.; Zachara, J. M; Lanigan, D. C.; Kutnyakov, I. V.; Burke, D. B.; Horton, D. G.; Serne, J. N.; Clayton, R. E.; Mitroshkov, A. V. Characterization of Uncontaminated Sediments from the Hanford Reservation-RCRA Borehole Core Samples and Composite Samples, 2001b, DE-AC0676RLO 1830.

(16) Steefel, C. I.; Lichtner, P. C. Geochim. Cosmochim. Acta, 1994, 58, 3595-3612.

(17) Steefel, C. I.; Lichtner, P. C. J. Hydrol., 1998, 209, 186-199.

(18) Lichtner, P. C.; Flemy, A. Computers \& Geosciences, 2003, 29, 371-383.

(19) Dove, P. M. Am. J. Sci. 1994, 294, 665-712.

(20) Rimstidt, J.D.; Barnes, H.L. Geochim. Cosmochim. Acta, 1980, 44, 1683-1699.

(21) Oelkers, E.H. J. Conference Abstracts, 2000, 5, 748.

(22) Brady, P. V.; Walther, J. V. Geochim. Cosmochim. Acta, 1989, 53, 2823-2830.

(23) Walther, J. V. Am. J. Sci., 1996, 296, 693-728.

(24) Worley, W. G.; Tester, J. W.; Grigsby, C. O. AIChE J., 1996, 42, 3442-3457.

(25) Park H.; Englezos P. Fluid Phase Equilibria, 1998, 153, 87-104.

(26) Fechtelkord, M.; Posnatzki, B.; Buhl, J. C. Chem. Mater. 2001, 13, 1967-1975.

(27) Buhl, J. C.; Stief, F.; Fechtelkord, M.; Gesing, T. M.; Taphorn, U.; Taake, C. J. Alloys and Compounds, 2000, 305, 93-102.

(28) Bosnar, S.; Subotic, B. Microporous and Mesoporous Materials 1999, 28, 483-493.

(29) Ghobarkar, H.; Schaf, O.; Paz, B.; Knauth, P. J. Solid State Chem. 2003, 173, 27-31.

(30) Grizzetti, R.; Artioli, G. Microporous and Mesoporous Materials 2002, 54, 105-112.

(31) Park, H.; Englezos, P. Ind. Eng. Chem. Res. 1999, 38, 4959-4965.

(32) Mostafa, A. T. M. G.; Eakman, J. E.; Yarbro, S. Ind. Eng.Chem.Res., 1995, 34, 4577- 4582. 
(33) Mostafa, A. T. M. G.; Eakman, J. E.; Montoya, M. M.; Yarbro, S.L. Ind. Eng.Chem. Res., 1996, 35, 343-348.

\section{Figure captions}

Figure 1. Cross section of Well C3082 (SX-108) Slant Borehole, locations of samples, and pH and sodium concentration profiles of pore waters from borehole samples (after Serne et al., 2001a)

Figure 2. Schematics of the plume profiling experiment design. The TWS was injected from the bottom of columns of different lengths. Injection was stopped when the effluent was just detected at the top. The column was sectioned and pore liquid was extracted from each section. The $\mathrm{pH}$ and EC were measured and data were graphed in a reverse direction to reflect the field geometry.

Figure 3. The $\mathrm{pH}$ and $\mathrm{EC}$ profiles along the $0.2,0.5$, and $2.0 \mathrm{~m}$ tall columns, with the distance axis normalized to the plume front position. The plume front was determined by using the inflection point of the normalized EC profile.

Figure 4. Breakthrough curves with four inflow solutions of different $\mathrm{Na}^{+}$concentrations: 8.0, 5.0, 3.0, and 1.0 M, with a common $\mathrm{OH}^{-}$concentration of $1.0 \mathrm{M}$.

Figure 5. Breakthrough curves with four inflow solutions of $\mathrm{pH}=13.8,12.9,10.8$, and 9.3, with a common $I=8.0 \mathrm{M}\left(\mathrm{NaNO}_{3}+\mathrm{NaOH}\right)$. The pore volume scale is relative to the cumulative injection volume. 
Figure 6. Breakthrough curves of the synthetic TWS ( $\mathrm{pH}=14.2$ and $I=8.0 \mathrm{M}$ ) permeated through three different types of sediment columns: Hanford sediment, Altamont soil, and pure quartz sand. The plume front is determined by the inflection points of the normalized EC curves.

Figure 7. Plume $\mathrm{pH}$ profiles along a $0.5 \mathrm{~m}$ Hanford column at different aging times. Experimental data and model calculations are shown as points and curves, respectively.

Figure 8. The $\mathrm{pH}$ changes with time in the batch tests. Measurements and simulation results are shown as data points and curve, respectively. 


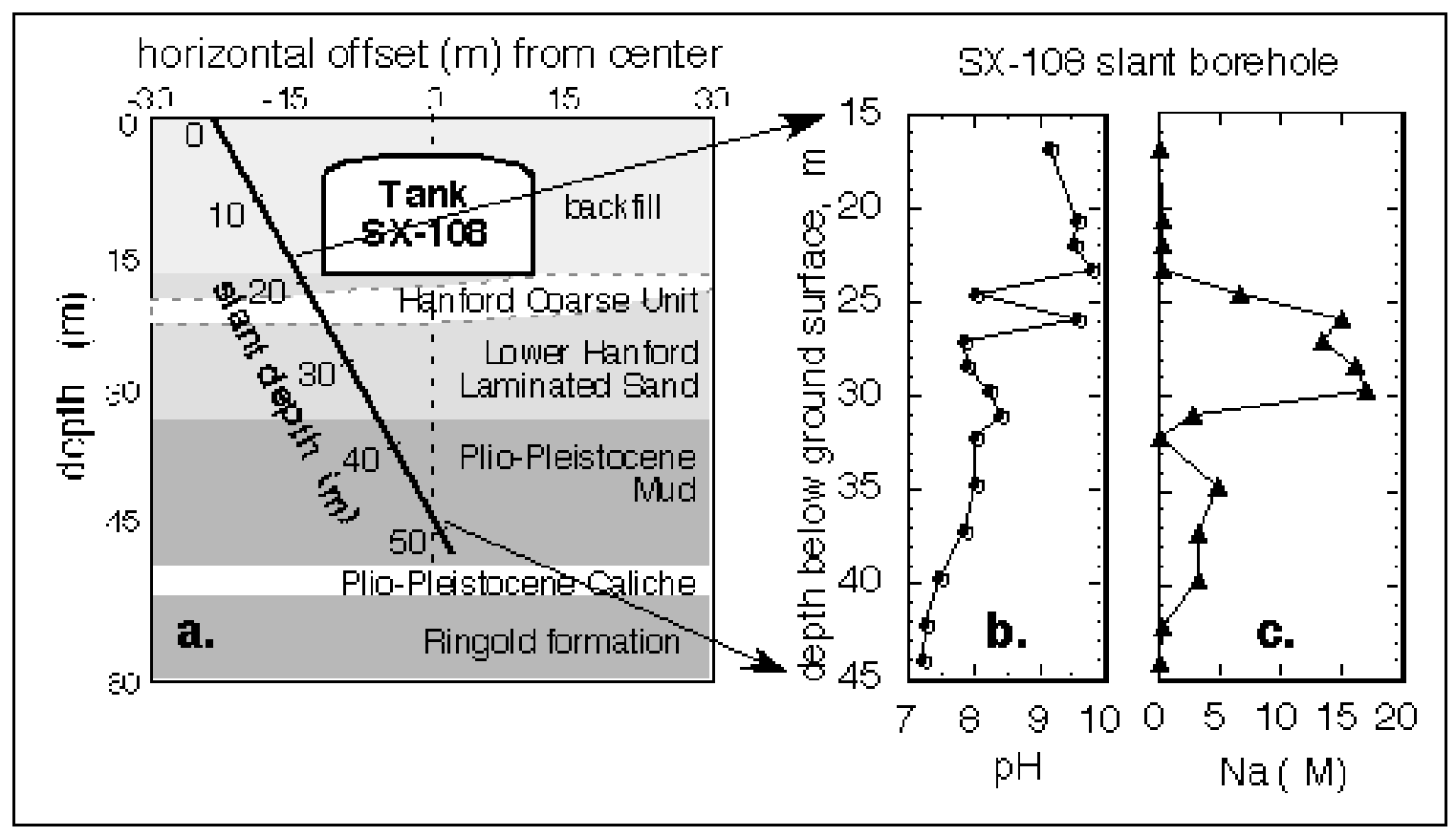

Figure 1. Cross section of Well C3082 (SX-108) Slant Borehole, locations of samples, and pH and sodium concentration profiles of pore waters from borehole samples (after Serne et al., 2001a) 


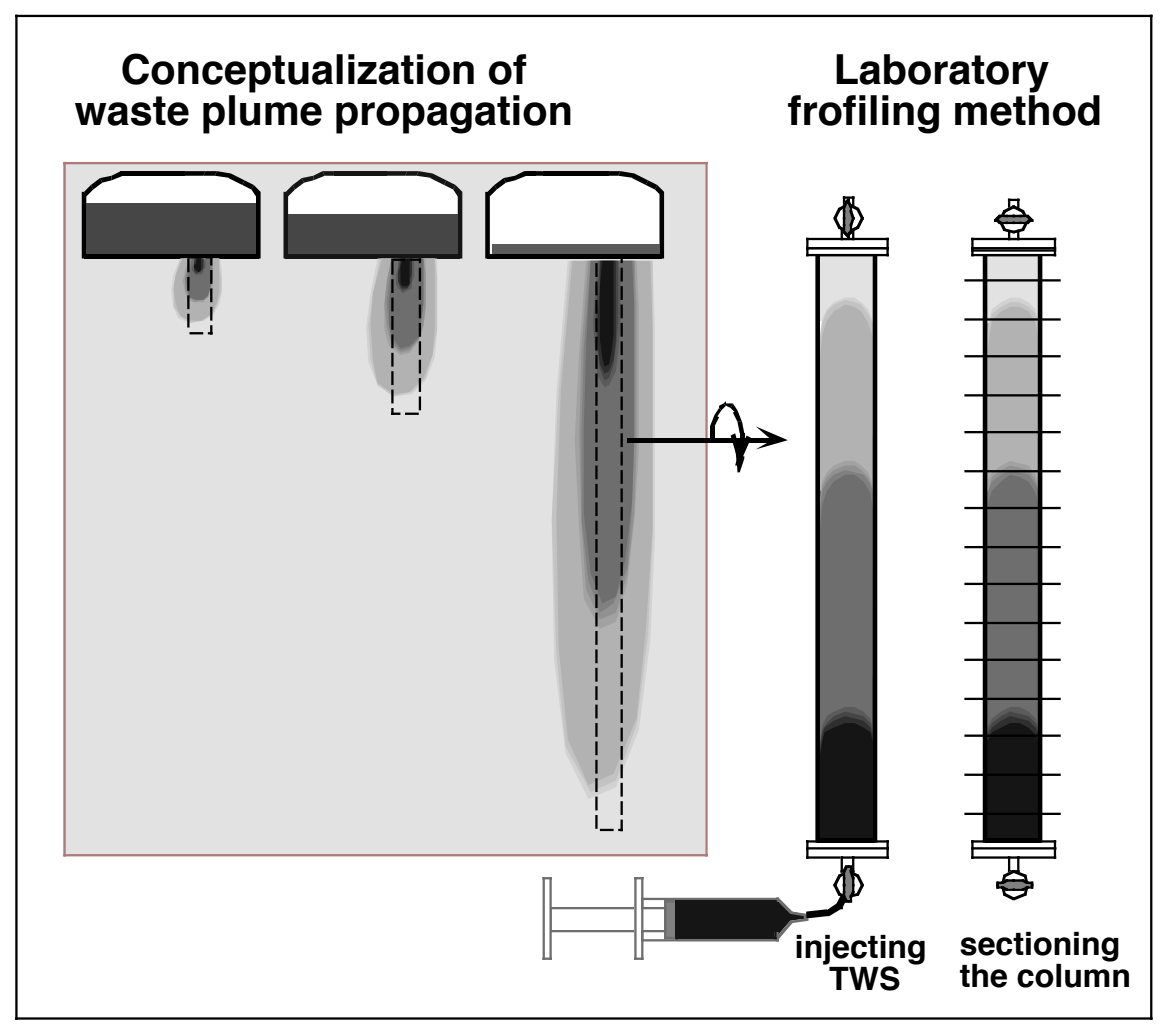

Figure 2. Schematics of the plume profiling experiment design. The TWS was injected from the bottom of columns of different lengths. Injection was stopped when the effluent was just detected at the top. The column was sectioned and pore liquid was extracted from each section. The $\mathrm{pH}$ and EC were measured and data were graphed in a reverse direction to reflect the field geometry. 

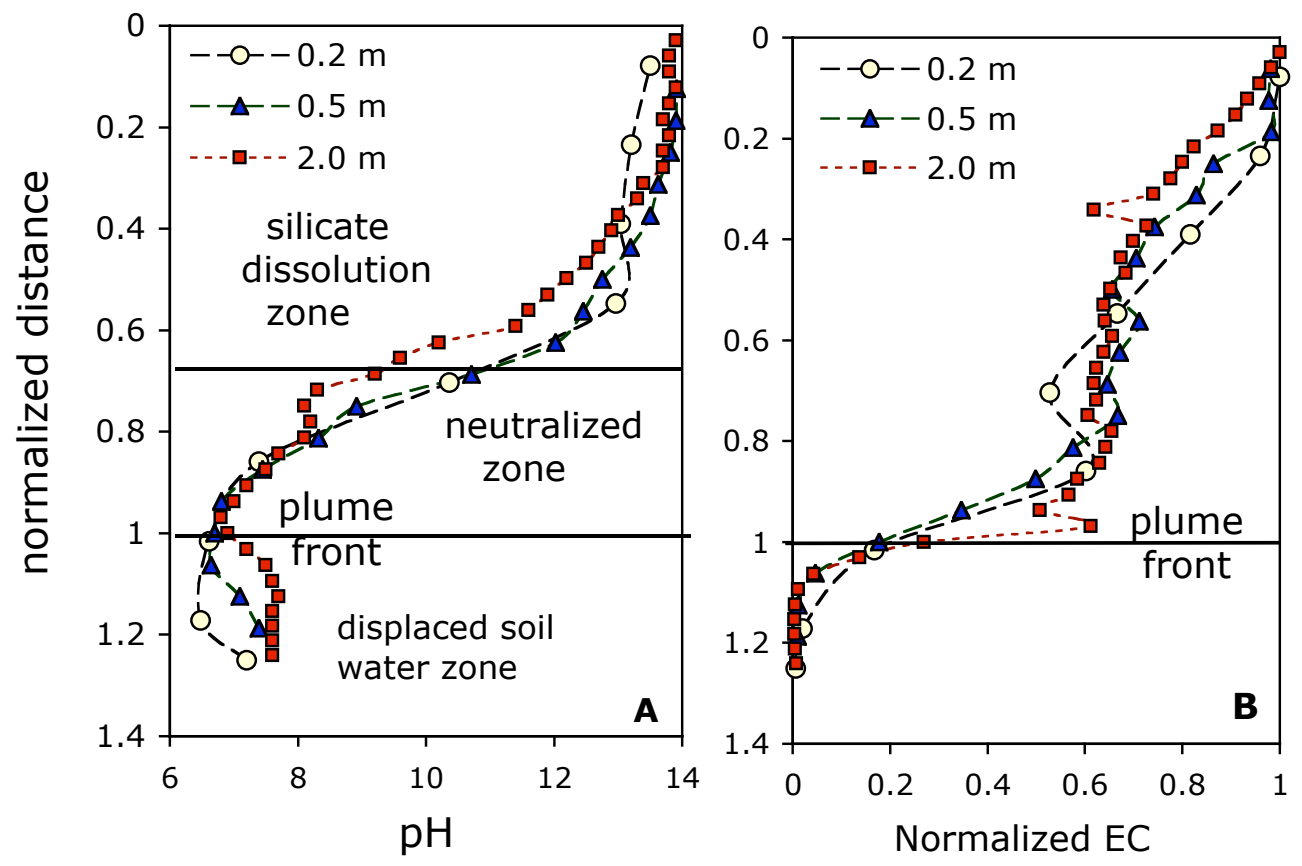

Figure 3. The $\mathrm{pH}$ and EC profiles along the $0.2,0.5$, and $2.0 \mathrm{~m}$ tall columns, with the distance axis normalized to the plume front position. The plume front was determined by using the inflection point of the normalized EC profile. 


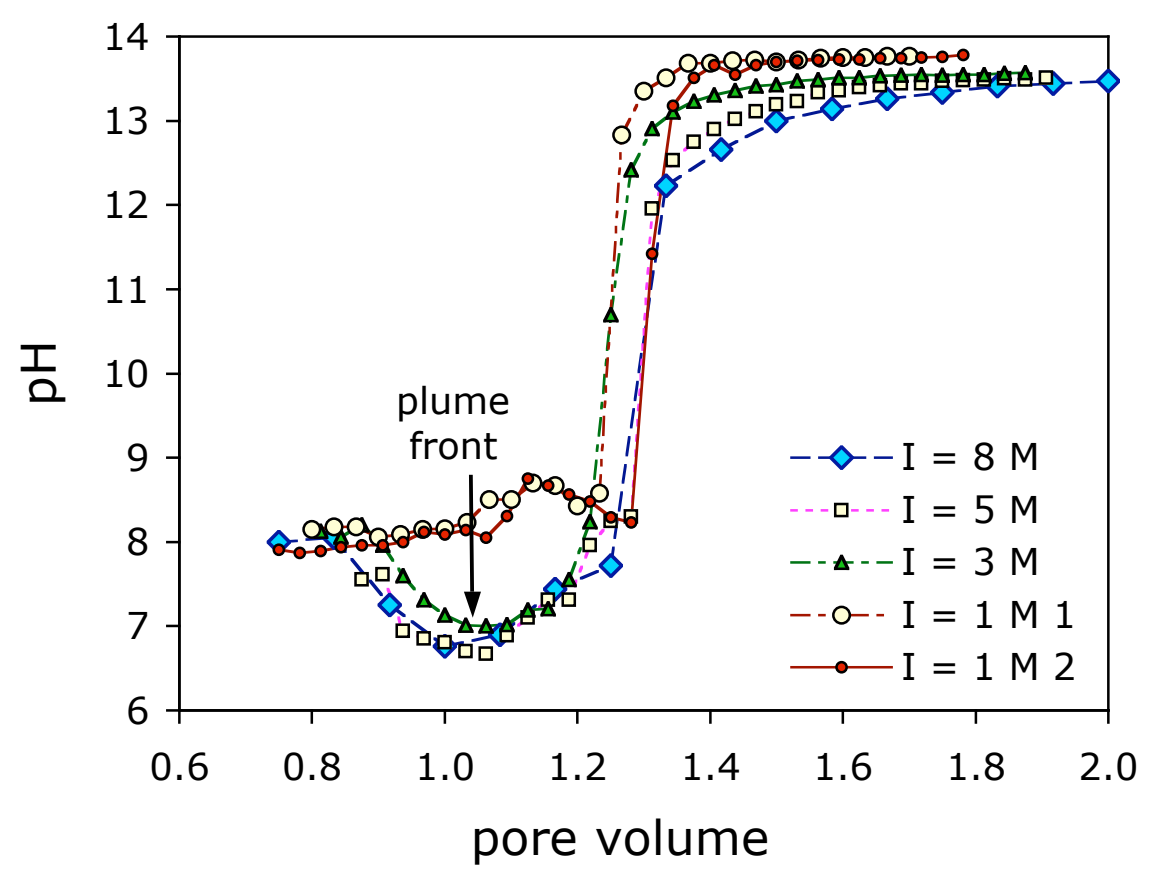

Figure4. Breakthrough curves with four inflow solutions of different $\mathrm{Na}^{+}$concentrations: 8.0, 5.0, 3.0, and $1.0 \mathrm{M}$, with a common $\mathrm{OH}^{-}$concentration of $1.0 \mathrm{M}$. 


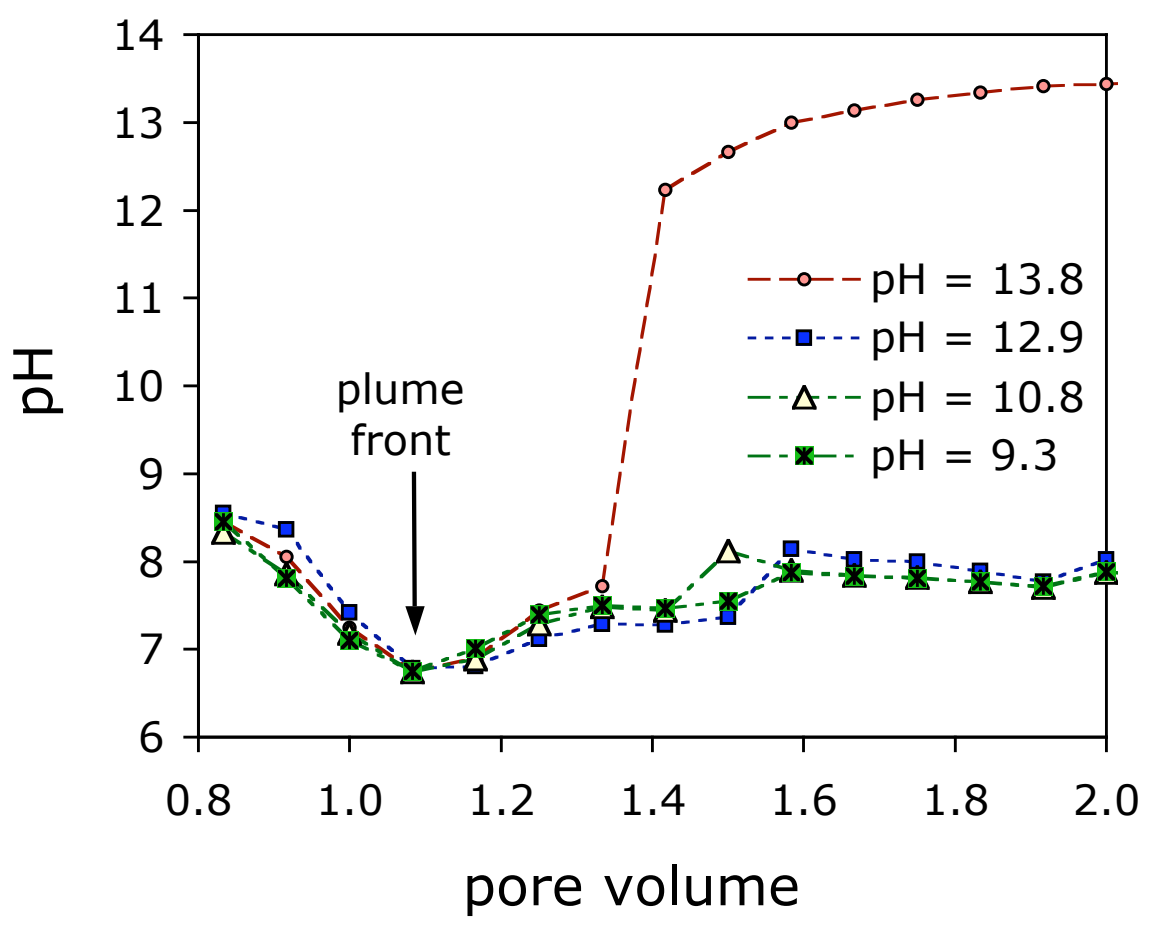

Figure 5. Breakthrough curves with four inflow solutions of $\mathrm{pH}=13.8,12.9,10.8$, and 9.3, with a common $I=8.0 \mathrm{M}\left(\mathrm{NaNO}_{3}+\mathrm{NaOH}\right)$. The pore volume scale is relative to the cumulative injection volume. 

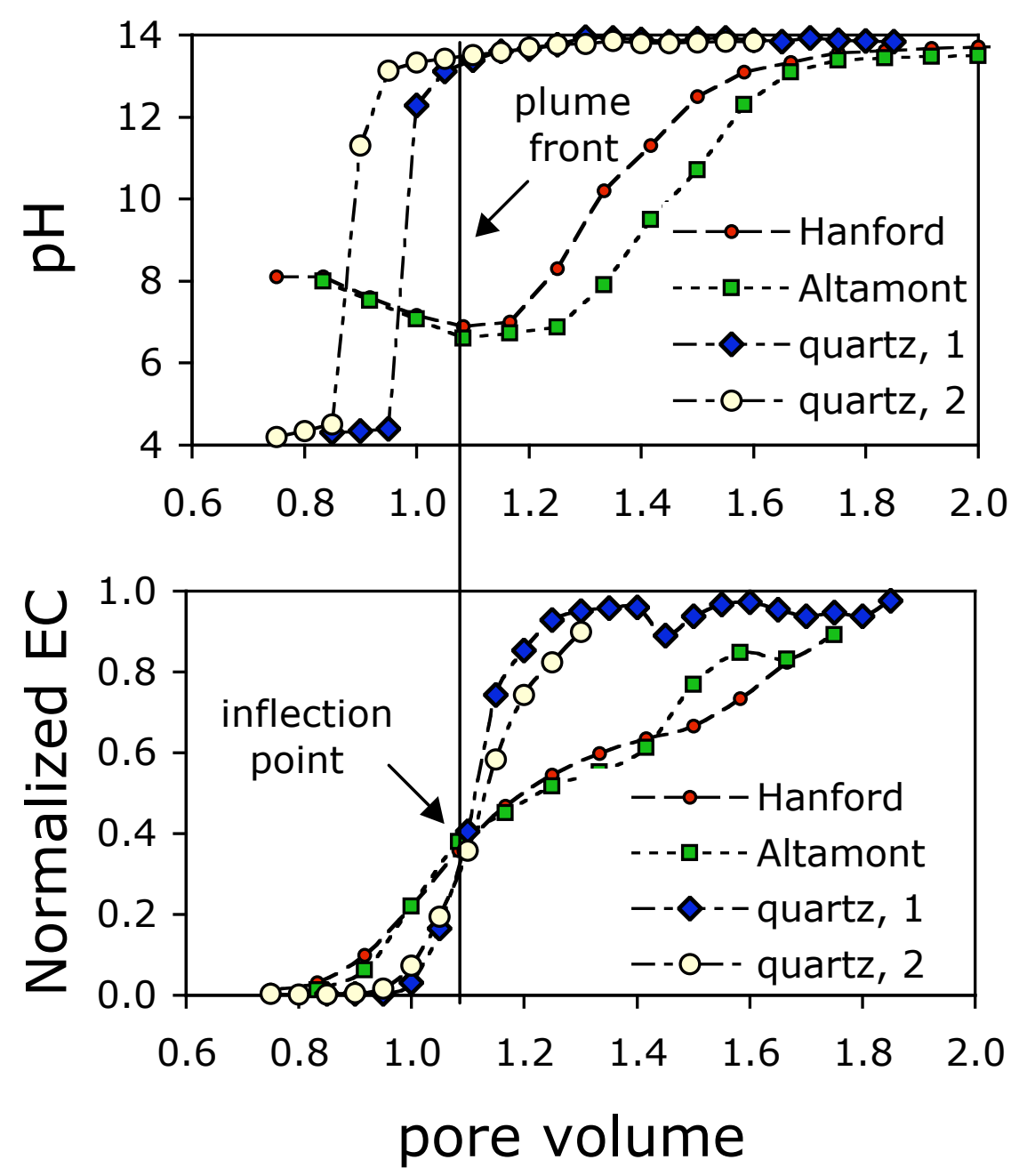

Figure 6. Breakthrough curves of the synthetic TWS $(\mathrm{pH}=14.2$ and $I=8.0 \mathrm{M})$ permeated through three different types of sediment columns: Hanford sediment, Altamont soil, and pure quartz sand. The plume front is determined by the inflection points of the normalized EC curves. 


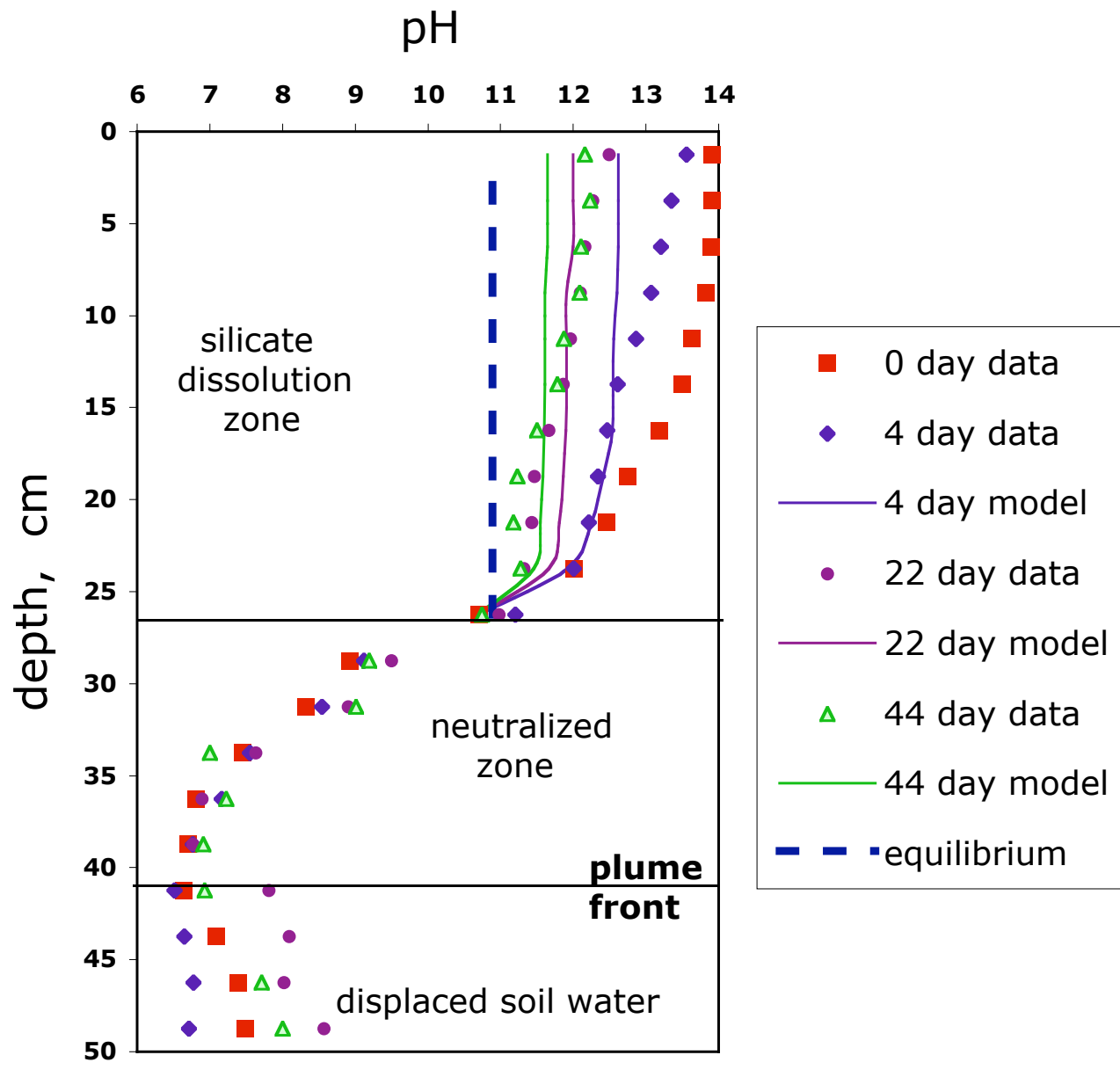

Figure 7. Plume $\mathrm{pH}$ profiles along a $0.5 \mathrm{~m}$ Hanford column at different aging times. Experimental data and model calculations are shown as points and curves respectively. 


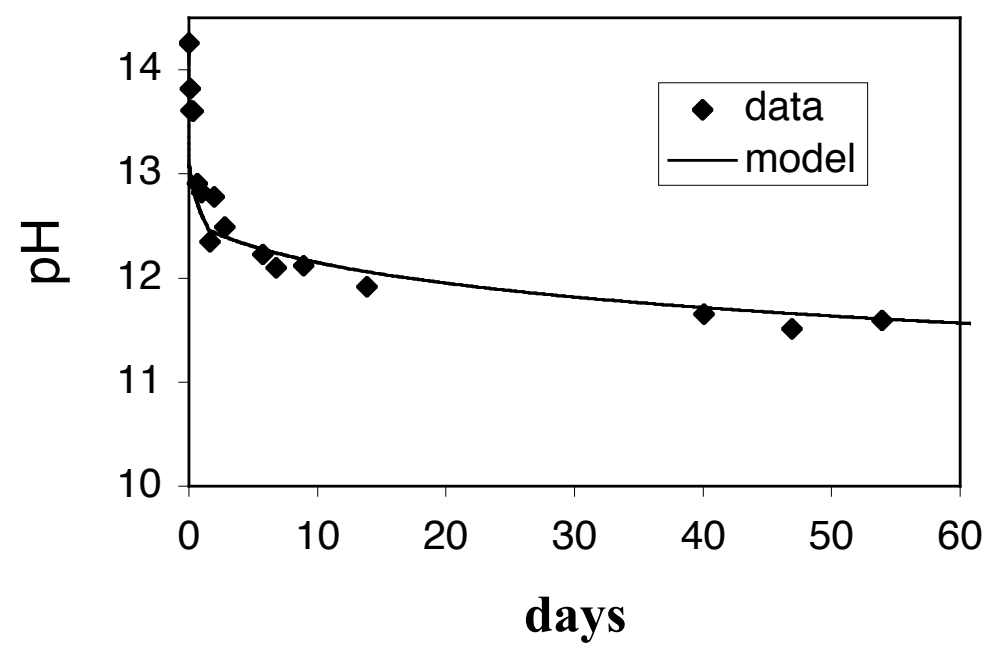

Figure 8. The $\mathrm{pH}$ changes with time in the batch tests. Measurements and simulation results are shown as data points and curve, respectively. 